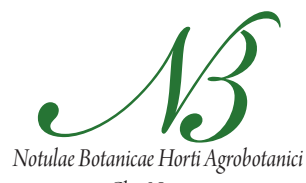

Cluj-Napoca

\title{
Graft-take Success in Walnut Under Controlled Conditions and Plant Development in the Nursery
}

\author{
Svetlana M. PAUNOVIĆ ${ }^{1}$, Rade MILETIC ${ }^{1}$, Milisav MITROVIĆ $^{2}$, Dragan JANKOVIĆ 3 \\ ${ }^{1}$ Fruit Research Institute, Kralja Petra I/9, 32000 Čačak, Serbia; paunovic59@sbb.rs \\ ${ }^{2}$ School of Professional Studies in Agriculture, Vojvode Putnika 56, 15000 Šabac, Serbia \\ ${ }^{3}$ Faculty of Agriculture Lešak, Kopaoniča bb, 38210, Lešak, Serbia
}

\begin{abstract}
The production of walnut nursery plants is a complex process, being dependent upon a range of factors that affect graft-take success and behaviour of walnut plants in the nursery. The experiment included two parts. Three different treatments were used in the heated room under controlled air temperature and humidity conditions: Treatment 1-grafting without paraffin treatment of the scion and graft union, coupled with covering the graft with sawdust up to the top of the scion; Treatment 2-grafting involving paraffin treatment of the scion and graft union, coupled with covering the graft with sawdust up to the top of the scion; and Treatment 3-grafting involving paraffin treatment of the scion and graft union, coupled with covering the graft with both sawdust up to the top of the scion and polyethylene foil. The treatments were evaluated for their effect on graft-take success. Graft planting in the nursery was followed by two treatments: treatment without foliar fertilisation and treatment with foliar fertilisation. Under controlled conditions, treatment 3 induced a higher graft-take success as compared to the other two treatments, whereas foliar fertilisation in the nursery had a positive effect on the survival, production of class 1 plants and vegetative growth of walnut plants.
\end{abstract}

Keywords: graft, foliar fertilisation, nursery, walnut nursery plant

\section{Introduction}

Walnut cultivation technology involves a number of organisational and cultural operations including scion and rootstock production, preparation of graft components for grafting, planting and handling of plants in the nursery (Tsurkan, 1990). Grafting success in walnut using the whip-and-tongue technique under controlled conditions is dependent upon choice of cultivars and rootstocks (Mitrović et al., 2008), time of scionwood collection from parent trees (Paunović et al., 2012), time and method of grafting (Solar et al., 2001; Tshering et al., 2006), and air temperature and relative humidity inside the callusing room (Avanzato, 2009; Barut, 2001), whereas nursery plant cultivation is contingent upon environmental conditions, and care and handling operations. Paunović (2010) reports that walnut plant production is a complex process, resulting in an unsatisfactory graft-take success rate as compared to other fruits (60-80\%), and the percentage of class 1 nursery plants of as low as 50-60\% of the total number of grafted rootstocks. The author also indicates that the use of foliar fertilisation in walnut nursery plant production has been negligible, regardless of its reportedly positive effect in terms of enhanced development of the root system, improved lignification and apical bud development, increased graft survival rate, increased percentage of class 1 plants and intensive vegetative growth of walnut plants.
The objective of this study was to evaluate the effect of different treatments on the graft-take success under controlled conditions, and observe the effect of foliar fertilisation on the survival rate and vegetative growth of nursery plants.

\section{Materials and methods}

The experiment was conducted at the Fruit Research Institute, Čačak, Serbia, over 2003-2005. One-year-old seedlings of domestic walnut (Juglans regia L.) $8-14 \mathrm{~mm}$ in thickness were grafted with scions of cvs. 'Seinovo' (control), 'Ovcar,' 'Elit,' 'G-286' and 'G-139'. Grafting was performed on 4 April 2003 and 2004 by whip-and-tongue grafting in the root crown zone on a sample of 30 grafts per replication, following a randomised block design (5 cultivars $\times 3$ treatments $\times 4$ replications), totalling 1800 grafted rootstocks. In order to stimulate callus formation, the grafts were kept in a heated room under controlled conditions at $26-28^{\circ} \mathrm{C}$ in 2003 , and $28-29^{\circ} \mathrm{C}$ in 2004 . Relative air humidity inside the heated room in 2003 and 2004 ranged from 60 to $70 \%$. The callusing period lasted 28 days. Three treatments were employed in the heated room under controlled conditions: Treatment 1-grafting without paraffin treatment of the scion and graft union, coupled with covering the graft with sawdust up to the top of the scion; Treatment 2-grafting involving paraffin treat- 
ment of the scion and graft union (paraffin temperature $60-70^{\circ} \mathrm{C}$ ), coupled with covering the graft with sawdust up to the top of the scion; and Treatment 3-grafting involving paraffin treatment of the scion and graft union, coupled with covering the graft with both sawdust up to the top of the scion and polyethylene foil.

Grafts were planted in the nursery on 20 May 2003 and 25 May 2004. The experiment was laid out in a randomised block design ( 5 cultivars $\times 2$ treatments $\times 4$ replications), with 34 grafts per replication, giving a total of 1360 planted grafts. Two treatments were used in the nursery: Treatment 1-without foliar fertilisation (control); and Treatment 2-with foliar fertilisation. Foliar fertilisation of walnut nursery plants was performed using Humisol containing $15 \%$ humic acid, $0.5 \% \mathrm{~N}, 2 \% \mathrm{~K}_{2} \mathrm{O}$ and $2 \%$ macro- and micro-nutrients (Ca, S, Mg, Zn, Fe, Cu, B, Mn). During the first year after graft planting in the nursery, two irrigation treatments, each using $0.1 \%$ Humisol solution, were applied on 20 May and 10 July 2003 and 25 May and 9 July 2004, and one foliar treatment with $2.5 \%$ Humisol solution was conducted on 18 August 2003 and 18 August 2004. During the second growing season, three foliar applications of Humisol were used: on 12 May, 23 June and 22 July 2004, and on 18 May, 20 June and 20 July 2005. Upon shoot emergence during both growing seasons, plant growth was evaluated at twenty-day intervals.

The following parameters were observed during the experiment: 1-graft-take success on day 20 after grafting, 2-graft-take success on day 28 after grafting, 3-survival rate of nursery plants at the end of the first growing season, 4-survival rate of different classes of nursery plants at the end of the second growing season, 5-growth of nursery plants at the end of the first growing season, 6-growth of nursery plants at the end of the second growing season.

The data obtained were subjected to Fisher's model of a three-factor analysis of variance-ANOVA. The significance of differences between the means for the control cultivar and those for the other selections at $p \leq 0.01$ and $p \leq 0.05$ was defined using Dunnett's one- and two-sided comparison test. The LSD test was performed at $p \leq 0.05$ to test the significance of differences between treatments and years as well as interaction means. The results are presented in tabular form.

\section{Results and discussion}

The relative air humidity and air temperature inside the heated room and sawdust temperature in 2003 and 2004 are presented in Tab. 1.
Graft-take success was evaluated on day 20 after grafting. Dunnett's test showed that cv. 'Seinovo' provided a highly significantly higher number of grafts exhibiting callus formation as compared to cvs. 'Ovcar', 'Elit' and 'G139'. No significant differences were observed between the control cultivar and 'G-286'. The average graft-take success on day 28 after grafting, as determined by Dunnett's test, showed that cv. 'Seinovo' had a highly significantly higher number of successful grafts as compared to the other cultivars. LSD-test revealed a significantly higher number of callused grafts on days 20 and 28 after grafting in the treatment involving the use of both paraffin and foil as compared to the other two treatments. A significant difference was observed between treatment 1 and treatment 2. In terms of years, a significantly lower number of callused grafts were observed in 2003 than in 2004 (Tab. 2).

Dunnett's test showed that at the end of the first growing season cv. 'Seinovo' gave a significantly higher number of survived nursery plants as compared to the other cultivars. At the end of the second growing season, Dunnett's test showed a significantly higher number of class 1 nursery plants in cv. 'Seinovo' than in the other test cultivars. A significant difference was observed in the number of class 2 nursery plants between the control cultivar, 'G-286' and 'Elit', whereas cvs. 'Seinovo', 'Ovcar' and 'G-139' displayed no difference. 'Seinovo' did not exhibit differences in the number of discarded nursery plants as compared to 'Ovcar', 'G-139' and 'Elit', but produced a significantly lower number of discarded nursery plants as compared to 'G-286'. LSD-test revealed that the treatment without foliar fertilisation (control) yielded a markedly lower number of survived nursery plants as compared to the treatment involving foliar fertilisation. A significantly higher number of survived nursery plants were obtained in 2004 than in 2003. At the end of the second growing season, LSD-test showed that foliar treatment gave a significantly higher number of class 1 nursery plants and a significantly lower number of class 2 and discarded nursery plants as compared to the unfertilised treatment (control). A significantly lower number of class 1 nursery plants were obtained in 2004, whereas no significant difference in the number of both class 2 and discarded nursery plants was observed in 2005 (Tab. 3).

At the end of the first growing season, Dunnett's test showed significantly higher vegetative growth in cv. 'Seinovo' as compared to cvs. 'Elit' and 'G-139', significantly lower growth as compared to 'G-286', and no difference between Šeinovo and 'Ovcar'. At the end of the second growing season, cv. 'Seinovo' exhibited significant-

Tab. 1. Relative air humidity (\%), air temperature inside the heated room and sawdust temperature $\left({ }^{\circ} \mathrm{C}\right)$ in 2003 and 2004

\begin{tabular}{cccccc}
\hline Year & $\begin{array}{c}\text { Relative air } \\
\text { humidity }\end{array}$ & $\begin{array}{c}\text { Heated room } \\
\text { temperature }\end{array}$ & $\begin{array}{c}\text { Sawdust temperature } \\
\text { Treatment 1 }\end{array}$ & $\begin{array}{c}\text { Sawdust temperature } \\
\text { Treatment 2 }\end{array}$ & $\begin{array}{c}\text { Sawdust temperature } \\
\text { Treatment 3 }\end{array}$ \\
\hline 2003 & $60.0-70.0$ & $26.0-28.0$ & $22.5-25.5$ & $23.5-26.0$ & $24.5-27.0$ \\
2004 & $60.0-70.0$ & $28.0-29.0$ & $25.0-26.5$ & $25.5-27.0$ & $26.5-28.0$ \\
\hline
\end{tabular}


172

Tab. 2. Graft-take success on days 20 and 28 after grafting

\begin{tabular}{|c|c|c|c|c|c|}
\hline & & $\begin{array}{l}\text { Callused grafts on day } \\
20 \text { after grafting (\%) }\end{array}$ & $\begin{array}{l}\text { Grafts subjected to } \\
\text { further callusing }(\%)\end{array}$ & $\begin{array}{l}\text { Discarded } \\
\text { grafts }(\%)\end{array}$ & $\begin{array}{c}\text { Successful grafts on } \\
\text { day28 after grafting (\%) }\end{array}$ \\
\hline \multirow{5}{*}{ Cultivar (A) } & 'Ovcar' & $49.0 \pm 1.07^{* *}$ & $48.3 \pm 1.03^{* *}$ & $2.63 \pm 0.22 \mathrm{~ns}$ & $81.7 \pm 0.91^{* *}$ \\
\hline & 'Elit' & $42.3 \pm 1.18^{* *}$ & $55.3 \pm 1.10^{* *}$ & $2.50 \pm 0.29 \mathrm{~ns}$ & $79.0 \pm 0.67^{* *}$ \\
\hline & 'G-139’ & $43.0 \pm 1.12^{* *}$ & $54.3 \pm 0.99^{* *}$ & $2.63 \pm 0.24 \mathrm{~ns}$ & $74.7 \pm 1.08^{* *}$ \\
\hline & 'G-286' & $60.7 \pm 0.99 \mathrm{~ns}$ & $38.0 \pm 0.97 \mathrm{~ns}$ & $1.37 \pm 0.16 \mathrm{~ns}$ & $88.0 \pm 0.57^{* *}$ \\
\hline & 'Seinovo' & $62.0 \pm 1.05$ & $37.3 \pm 1.02$ & $0.57 \pm 0.10$ & $93.3 \pm 0.63$ \\
\hline \multirow{3}{*}{ Treatment (B) } & Without paraffin & $32.3 \pm 0.57 \mathrm{c}$ & $64.0 \pm 0.53 \mathrm{a}$ & $3.57 \pm 0.22 \mathrm{a}$ & $72.0 \pm 0.70 \mathrm{c}$ \\
\hline & With paraffin & $54.0 \pm 0.58 \mathrm{~b}$ & $44.3 \pm 0.57 \mathrm{~b}$ & $1.57 \pm 0.15 b$ & $85.3 \pm 0.48 b$ \\
\hline & Paraffin and foil & $67.8 \pm 0.65 \mathrm{a}$ & $31.4 \pm 0.64 \mathrm{c}$ & $0.67 \pm 0.06 \mathrm{~b}$ & $92.7 \pm 0.44 \mathrm{a}$ \\
\hline \multirow{2}{*}{ Year $(\mathrm{C})$} & 2003 & $47.3 \pm 0.73 b$ & $50.4 \pm 0.66 \mathrm{~b}$ & $2.27 \pm 0.16 \mathrm{a}$ & $76.7 \pm 0.57 \mathrm{~b}$ \\
\hline & 2004 & $55.5 \pm 0.74 \mathrm{a}$ & $42.8 \pm 0.72 \mathrm{a}$ & $1.60 \pm 0.11 \mathrm{a}$ & $90.0 \pm 0.41 \mathrm{a}$ \\
\hline \multicolumn{6}{|c|}{$\mathrm{A} \times \mathrm{B}$} \\
\hline \multirow{3}{*}{ 'Ovcar' } & Without paraffin & 28.7 & 66.3 & 5.00 & $72.0 \mathrm{f}$ \\
\hline & With paraffin & 53.0 & 45.3 & 1.67 & $83.0 \mathrm{de}$ \\
\hline & Paraffin and foil & 65.3 & 33.2 & 1.23 & $90.0 \mathrm{bc}$ \\
\hline \multirow{3}{*}{ 'Elit' } & Without paraffin & 20.4 & 75.0 & 4.57 & $65.7 \mathrm{~g}$ \\
\hline & With paraffin & 43.7 & 53.5 & 2.90 & $82.0 \mathrm{de}$ \\
\hline & Paraffin and foil & 62.7 & 37.3 & 0.00 & $89.3 \mathrm{bc}$ \\
\hline \multirow{3}{*}{ 'G-139’ } & Without paraffin & 25.0 & 70.0 & 5.00 & $58.3 \mathrm{~h}$ \\
\hline & With paraffin & 49.0 & 49.2 & 1.67 & $78.7 \mathrm{e}$ \\
\hline & Paraffin and foil & 55.0 & 43.7 & 1.23 & $86.7 \mathrm{~cd}$ \\
\hline \multirow{3}{*}{ 'G-286' } & Without paraffin & 43.3 & 54.7 & 2.07 & $79.3 \mathrm{e}$ \\
\hline & With paraffin & 61.3 & 37.3 & 1.23 & $87.7 \mathrm{~cd}$ \\
\hline & Paraffin and foil & 77.5 & 21.7 & 0.83 & $97.0 \mathrm{a}$ \\
\hline \multirow{3}{*}{ 'Seinovo' } & Without paraffin & 44.0 & 54.7 & 1.27 & $84.0 \mathrm{cde}$ \\
\hline & With paraffin & 63.0 & 36.3 & 0.40 & $95.7 \mathrm{ab}$ \\
\hline & Paraffin and foil & 78.7 & 21.2 & 0.00 & $100.0 \mathrm{a}$ \\
\hline \multicolumn{6}{|c|}{$\mathrm{A} \times \mathrm{C}$} \\
\hline \multirow{2}{*}{ 'Ovcar' } & 2003 & 44.7 & 52.6 & $2.50 \mathrm{ab}$ & 70.3 \\
\hline & 2004 & 53.3 & 44.0 & $2.76 \mathrm{ab}$ & 93.0 \\
\hline \multirow{2}{*}{ 'Elit' } & 2003 & 38.7 & 56.7 & $4.67 \mathrm{a}$ & 76.7 \\
\hline & 2004 & 45.7 & 54.0 & $0.30 \mathrm{~b}$ & 81.6 \\
\hline \multirow{2}{*}{ 'G-139’ } & 2003 & 37.3 & 59.7 & $2.77 \mathrm{ab}$ & 64.7 \\
\hline & 2004 & 48.7 & 48.7 & $2.50 \mathrm{ab}$ & 84.7 \\
\hline \multirow{2}{*}{ 'G-286' } & 2003 & 57.3 & 41.7 & $0.83 \mathrm{~b}$ & 84.3 \\
\hline & 2004 & 64.0 & 34.0 & $1.90 \mathrm{ab}$ & 91.6 \\
\hline \multirow{2}{*}{ 'Seinovo' } & 2003 & 58.0 & 41.3 & $0.57 \mathrm{~b}$ & 87.3 \\
\hline & 2004 & 66.0 & 33.3 & $0.57 \mathrm{~b}$ & 99.3 \\
\hline \multicolumn{6}{|c|}{$\mathrm{B} \times \mathrm{C}$} \\
\hline \multirow{2}{*}{$\begin{array}{l}\text { Without } \\
\text { paraffin }\end{array}$} & 2003 & 28.3 & $67.0 \mathrm{a}$ & 4.83 & 63.7 \\
\hline & 2004 & 36.3 & $61.0 \mathrm{a}$ & 2.30 & 80.0 \\
\hline \multirow{2}{*}{ With paraffin } & 2003 & 50.0 & $48.3 \mathrm{~b}$ & 1.67 & 79.6 \\
\hline & 2004 & 58.0 & $40.3 \mathrm{c}$ & 1.50 & 91.3 \\
\hline \multirow{2}{*}{$\begin{array}{l}\text { Paraffin } \\
\text { and foil }\end{array}$} & 2003 & 63.6 & $36.0 \mathrm{c}$ & 0.33 & 86.7 \\
\hline & 2004 & 72.3 & $26.7 \mathrm{~d}$ & 1.00 & 98.7 \\
\hline \multicolumn{6}{|l|}{ ANOVA } \\
\hline Cultivar (A) & & ** & ** & ns & ** \\
\hline Treatment (B) & & ** & ${ }^{* *}$ & $* *$ & ** \\
\hline Year $(\mathrm{C})$ & & $* *$ & ** & ns & ** \\
\hline $\mathrm{A} \times \mathrm{B}$ & & ns & ns & ns & $*$ \\
\hline $\mathrm{A} \times \mathrm{C}$ & & ns & ns & $*$ & $* *$ \\
\hline $\mathrm{B} \times \mathrm{C}$ & & ns & $* *$ & ns & ns \\
\hline $\mathrm{A} \times \mathrm{B} \times \mathrm{C}$ & & & ${ }^{* *} \mathrm{~ns}$ ns ns & & \\
\hline
\end{tabular}

A, B, C represent cultivars, treatments and years, respectively. The asterisks in vertical columns represent significant differences between means at $p \leq 0.05$ and $p \leq 0.01$ according to Dunnett's test and ANOVA (F-test) results; ns- non-significant. The values within treatment, year and interaction mean columns designated with the same small letters do not differ significantly at $p \leq 0.05$ according to LSD-test 
Tab. 3. Survival rate of walnut nursery plants at the end of the first growing season, and nursery plant classes at the end of the second growing season

\begin{tabular}{|c|c|c|c|c|c|}
\hline & & $\begin{array}{l}\text { Survived plants at } \\
\text { the end of the } 1 \text { st } \\
\text { growing season }(\%)\end{array}$ & $\begin{array}{l}\text { Class } 1 \text { plants at } \\
\text { the end of the } 2 \text { nd } \\
\text { growing season (\%) }\end{array}$ & $\begin{array}{l}\text { Class } 2 \text { plants at } \\
\text { the end of the } 2 \text { nd } \\
\text { growing season }(\%)\end{array}$ & $\begin{array}{l}\text { Discarded plants at } \\
\text { the end of the } 2 \text { nd } \\
\text { growing season }(\%)\end{array}$ \\
\hline \multirow{5}{*}{ Cultivar (A) } & 'Ovcar' & $77.1 \pm 0.92^{* *}$ & $63.5 \pm 0.99^{* *}$ & $6.44 \pm 0.21 \mathrm{~ns}$ & $6.97 \pm 0.20 \mathrm{~ns}$ \\
\hline & 'Elit' & $77.1 \pm 0.68^{* *}$ & $60.3 \pm 0.81^{* *}$ & $9.91 \pm 0.26^{*}$ & $6.97 \pm 0.26 \mathrm{~ns}$ \\
\hline & 'G-139’ & $74.1 \pm 0.92^{* *}$ & $60.0 \pm 1.02^{* *}$ & $7.35 \pm 0.25 \mathrm{~ns}$ & $6.79 \pm 0.20 \mathrm{~ns}$ \\
\hline & 'G-286' & $84.1 \pm 0.64^{* *}$ & $65.9 \pm 0.96^{* *}$ & $9.56 \pm 0.25^{*}$ & $8.62 \pm 0.26^{* *}$ \\
\hline & 'Seinovo' & $88.8 \pm 0.58$ & $75.0 \pm 0.78$ & $7.53 \pm 0.16$ & $6.23 \pm 0.24$ \\
\hline \multirow{2}{*}{ Treatment (B) } & Control & $75.3 \pm 0.44 b$ & $56.8 \pm 0.44 b$ & $9.56 \pm 0.14 \mathrm{a}$ & $8.88 \pm 0.13 \mathrm{a}$ \\
\hline & Fertilisation & $85.3 \pm 0.53 \mathrm{a}$ & $73.2 \pm 0.50 \mathrm{a}$ & $6.76 \pm 0.13 b$ & $5.35 \pm 0.10 \mathrm{~b}$ \\
\hline \multirow{2}{*}{ Year (C) } & 2003 & $74.1 \pm 0.47 \mathrm{~b}$ & $59.4 \pm 0.54 \mathrm{~b}$ & $7.79 \pm 0.15 \mathrm{a}$ & $6.91 \pm 0.17 \mathrm{a}$ \\
\hline & 2004 & $86.2 \pm 0.43 \mathrm{a}$ & $70.6 \pm 0.59 \mathrm{a}$ & $8.53 \pm 0.16 \mathrm{a}$ & $7.35 \pm 0.13 \mathrm{a}$ \\
\hline \multicolumn{6}{|c|}{$A \times B$} \\
\hline \multirow{2}{*}{ 'Ovcar' } & Control & 71.8 & 55.9 & 7.35 & 8.44 \\
\hline & Fertilisation & 82.3 & 71.2 & 5.50 & 5.50 \\
\hline \multirow{2}{*}{ 'Elit' } & Control & 71.8 & 52.0 & 11.80 & 8.44 \\
\hline & Nutrition & 82.3 & 68.8 & 8.09 & 5.50 \\
\hline \multirow{2}{*}{ ‘G-139’ } & Control & 70.3 & 52.6 & 9.56 & 8.09 \\
\hline & Fertilisation & 78.2 & 67.6 & 5.15 & 5.50 \\
\hline \multirow{2}{*}{ 'G-286’ } & Control & 78.5 & 56.5 & 10.70 & 11.40 \\
\hline & Fertilisation & 89.7 & 75.3 & 8.44 & 5.88 \\
\hline \multirow{2}{*}{ 'Seinovo' } & Control & 84.1 & 67.6 & 8.44 & 8.09 \\
\hline & Fertilisation & 93.8 & 82.6 & 6.62 & 4.41 \\
\hline \multicolumn{6}{|c|}{$\mathrm{A} \times \mathrm{C}$} \\
\hline \multirow{2}{*}{ 'Ovcar' } & 2003 & $68.5 \mathrm{~g}$ & $55.9 \mathrm{e}$ & 5.88 & 6.62 \\
\hline & 2004 & $85.6 \mathrm{bc}$ & $71.2 \mathrm{~b}$ & 6.97 & 7.35 \\
\hline \multirow{2}{*}{ 'Elit' } & 2003 & $72.6 \mathrm{f}$ & $57.9 \mathrm{de}$ & 8.44 & 6.23 \\
\hline & 2004 & 81.5 de & $62.6 c$ & 11.40 & 7.70 \\
\hline \multirow{2}{*}{ ‘G-139’ } & 2003 & $64.7 \mathrm{~g}$ & $51.8 \mathrm{f}$ & 6.97 & 5.88 \\
\hline & 2004 & $83.8 \mathrm{cde}$ & $68.5 \mathrm{~b}$ & 7.73 & 7.70 \\
\hline \multirow{2}{*}{ 'G-286' } & 2003 & $80.6 \mathrm{e}$ & $60.9 \mathrm{~cd}$ & 10.30 & 9.18 \\
\hline & 2004 & $87.9 \mathrm{~b}$ & $70.9 \mathrm{~b}$ & 8.82 & 8.09 \\
\hline \multirow{2}{*}{ 'Seinovo' } & 2003 & $85.0 \mathrm{bcd}$ & $70.9 \mathrm{~b}$ & 7.35 & 6.62 \\
\hline & 2004 & $92.6 \mathrm{a}$ & $79.4 \mathrm{a}$ & 7.71 & 5.88 \\
\hline \multicolumn{6}{|c|}{$\mathrm{B} \times \mathrm{C}$} \\
\hline \multirow{2}{*}{ Control } & 2003 & $70.3 c$ & $52.3 \mathrm{~d}$ & 9.26 & 8.82 \\
\hline & 2004 & $80.3 \mathrm{~b}$ & $61.7 \mathrm{c}$ & 9.85 & 8.97 \\
\hline \multirow{2}{*}{ Fertilisation } & 2003 & $78.5 \mathrm{~b}$ & $66.8 \mathrm{~b}$ & 6.32 & 5.00 \\
\hline & 2004 & $92.0 \mathrm{a}$ & $79.4 \mathrm{a}$ & 7.21 & 5.73 \\
\hline \multicolumn{6}{|l|}{ ANOVA } \\
\hline Cultivar (A) & & ** & ** & $* *$ & ** \\
\hline Treatment (B) & & ** & ** & ** & ** \\
\hline Year (C) & & ** & $* *$ & $\mathrm{~ns}$ & $\mathrm{~ns}$ \\
\hline$A \times B$ & & ns & ns & $\mathrm{ns}$ & ns \\
\hline $\mathrm{A} \times \mathrm{C}$ & & $* *$ & ** & $\mathrm{ns}$ & ns \\
\hline $\mathrm{B} \times \mathrm{C}$ & & ** & ** & $\mathrm{ns}$ & ns \\
\hline $\mathrm{A} \times \mathrm{B} \times \mathrm{C}$ & & $\mathrm{ns}$ & $\mathrm{ns}$ & ns & ns \\
\hline
\end{tabular}

A, B, C represent cultivars, treatments and years, respectively. The asterisks in vertical columns represent significant differences between means at $p \leq 0.05$ and $p \leq 0.01$ according to Dunnett's test and ANOVA (F-test) results; ns- non-significant. The values within treatment, year and interaction mean columns designated with the same small letters do not differ significantly at $p \leq 0.05$ according to LSD-test 
174

Tab. 4. Vegetative growth of nursery walnut plants

\begin{tabular}{|c|c|c|c|}
\hline & & $\begin{array}{l}\text { Vegetative growth of nursery plants at } \\
\text { the end of the first growing season }\end{array}$ & $\begin{array}{l}\text { Vegetative growth of nursery plants at } \\
\text { the end of the second growing season }\end{array}$ \\
\hline \multirow{5}{*}{ Cultivar (A) } & 'Ovcar' & $15.4 \pm 0.69 \mathrm{~ns}$ & $190.3 \pm 6.72 \mathrm{~ns}$ \\
\hline & 'Elit' & $14.8 \pm 0.66^{* *}$ & $183.1 \pm 6.82^{* *}$ \\
\hline & 'G-139’ & $14.7 \pm 0.75^{* *}$ & $182.2 \pm 5.58^{* *}$ \\
\hline & 'G-286 & $17.1 \pm 0.80^{* *}$ & $195.0 \pm 8.52 \mathrm{~ns}$ \\
\hline & 'Seinovo' & $15.9 \pm 0.60$ & $197.7 \pm 8.86$ \\
\hline \multirow{2}{*}{ Treatment (B) } & Control & $14.3 \pm 0.41 \mathrm{~b}$ & $171.6 \pm 2.35 \mathrm{~b}$ \\
\hline & Fertilisation & $16.9 \pm 0.36 \mathrm{a}$ & $207.8 \pm 4.51 \mathrm{a}$ \\
\hline \multirow{3}{*}{ Year $(\mathrm{C})$} & 2003 & $13.9 \pm 0.39 \mathrm{~b}$ & \\
\hline & 2004 & $17.4 \pm 0.25 a$ & $207.5 \pm 5.09 \mathrm{a}$ \\
\hline & 2005 & & $171.9 \pm 2.29 \mathrm{~b}$ \\
\hline \multirow{3}{*}{ 'Ovcar' } & & $\mathrm{A} \times \mathrm{B}$ & \\
\hline & Control & $14.5 \mathrm{e}$ & 174.5 \\
\hline & Fertilisation & $16.3 \mathrm{bc}$ & 206.2 \\
\hline \multirow{2}{*}{ 'Elit' } & Control & $13.5 \mathrm{f}$ & 165.5 \\
\hline & Fertilisation & $16.2 \mathrm{bc}$ & 200.8 \\
\hline \multirow{2}{*}{ ‘G 139’ } & Control & $13.8 \mathrm{ef}$ & 166.7 \\
\hline & Fertilisation & $15.7 \mathrm{~cd}$ & 197.8 \\
\hline \multirow{2}{*}{ ‘G 286’ } & Control & $15.0 \mathrm{de}$ & 173.8 \\
\hline & Fertilisation & $19.2 \mathrm{a}$ & 216.2 \\
\hline \multirow{2}{*}{ 'Seinovo' } & Control & $14.6 \mathrm{e}$ & 177.6 \\
\hline & Fertilisation & $17.2 \mathrm{~b}$ & 217.9 \\
\hline \multirow{4}{*}{ 'Ovcar' } & & $\mathrm{A} \times \mathrm{C}$ & \\
\hline & 2003 & $13.5 \mathrm{ef}$ & \\
\hline & 2004 & $17.3 \mathrm{~b}$ & $207.2 \mathrm{a}$ \\
\hline & 2005 & & $173.4 \mathrm{c}$ \\
\hline \multirow{3}{*}{ 'Elit' } & 2003 & $13.3 \mathrm{ef}$ & \\
\hline & 2004 & $16.4 b c$ & $199.7 \mathrm{~b}$ \\
\hline & 2005 & & $166.6 \mathrm{c}$ \\
\hline \multirow{3}{*}{ 'G 139’ } & 2003 & $12.4 \mathrm{f}$ & \\
\hline & 2004 & $17.1 \mathrm{~b}$ & $194.1 \mathrm{~b}$ \\
\hline & 2005 & & $170.4 \mathrm{c}$ \\
\hline \multirow{3}{*}{ 'G 286} & 2003 & $15.7 \mathrm{~cd}$ & \\
\hline & 2004 & $18.6 \mathrm{a}$ & $218.1 \mathrm{a}$ \\
\hline & 2005 & & $171.9 \mathrm{c}$ \\
\hline \multirow{3}{*}{ 'Seinovo' } & 2003 & $14.4 \mathrm{de}$ & \\
\hline & 2004 & $17.4 \mathrm{ab}$ & $218.3 \mathrm{a}$ \\
\hline & 2005 & & $177.2 \mathrm{bc}$ \\
\hline \multirow{4}{*}{ Control } & & $\mathrm{B} \times \mathrm{C}$ & \\
\hline & 2003 & $12.5 \mathrm{~d}$ & \\
\hline & 2004 & $16.2 \mathrm{~b}$ & $183.4 \mathrm{~b}$ \\
\hline & 2005 & & $159.9 \mathrm{c}$ \\
\hline \multirow{3}{*}{ Fertilisation } & 2003 & $15.3 \mathrm{c}$ & \\
\hline & 2004 & $18.6 \mathrm{a}$ & $231.7 \mathrm{a}$ \\
\hline & 2005 & & $184.0 \mathrm{~b}$ \\
\hline \multicolumn{4}{|l|}{ ANOVA } \\
\hline Cultivar (A) & & $* *$ & $* *$ \\
\hline Treatment (B) & & $* *$ & $* *$ \\
\hline Year (C) & & $* *$ & $* *$ \\
\hline$A \times B$ & & $* *$ & ns \\
\hline $\mathrm{A} \times \mathrm{C}$ & & * & $* *$ \\
\hline $\mathrm{B} \times \mathrm{C}$ & & ** & ** \\
\hline $\mathrm{A} \times \mathrm{B} \times \mathrm{C}$ & & $\mathrm{ns}$ & $\mathrm{ns}$ \\
\hline
\end{tabular}

A, B, C represent cultivars, treatments and years, respectively. The asterisks in vertical columns represent significant differences between means at $p \leq 0.05$ and $p \leq 0.01$ according to Dunnett's test and ANOVA (F-test) results; ns- non-significant. The values within treatment, year and interaction mean columns designated with the same small letters do not differ significantly at $p \leq 0.05$ according to LSD-test 
ly higher growth of nursery plants as compared to 'Elit' and 'G-139', whereas no difference was observed between 'Seinovo,' 'Ovcar' and 'G-286'. LSD-test revealed that the treatment without foliar fertilisation (control) stimulated significantly lower vegetative growth during the first and second growing seasons as compared to the foliar treatment. Significantly lower growth of nursery plants was recorded in 2003 and 2005 than in 2004 (Tab. 4).

The differences observed in graft-take success in the experiment were induced by the temperature inside the heated room and sawdust temperature, whereas the fluctuations in air humidity of $10 \%(60-70 \%)$ had no substantial effect, due to the fact that sawdust did not undergo desiccation in deeper layers but only in the top layer.

The highest sawdust temperature and the lowest temperature fluctuations were determined in the treatment involving paraffined foil-covered grafts. In this case, sawdust temperature was $1.5-2^{\circ} \mathrm{C}$ and $0.5-1^{\circ} \mathrm{C}$ higher than in the treatment without and with paraffin, respectively. The primary role of paraffin in walnut grafting is to prevent desiccation of the graft union and excessive loss of water from the scion, as the scion has no adequate water supply due to the absence of a connecting water-conducting vessel system between the scion and rootstock. Paraffin also helps in making close contact between the cambial zones of the graft components, thereby fixing them and preventing further movement, particularly upon initiation of multiplication of parenchymal cells at the cross-sections of the graft components. This facilitates meristematic cell division, callus tissue formation and differentiation of water-conducting vessels and other elements, and enhances callus bridge formation at the graft union and efficient adhesion between the rootstock and scion (Hartman et al., 1997). The foil prevented heat and moisture emission in the boxes with grafts, thereby ensuring higher uniformity of sawdust temperature with very few variations observed and preventing sawdust desiccation. Graft-take success on day 20 after grafting in paraffined and foil-covered grafts was $35.5 \%$ and $13.8 \%$ higher, respectively, as compared to that in the treatment without and with paraffin. Bulatović (1985) recommends covering walnut grafts with foil to ensure higher sawdust temperature, resulting in graft-take success of $65-90 \%$. In the absence of paraffin, the rootstock and the scion developed an insufficiently tight union, which hindered callusing and caused separation of the graft components in many cases. The present results are in agreement with the data obtained by Solar et al. (2001). The authors employed treatments with and without paraffin which gave a $83 \%$ and $77 \%$ graft-take success rate, respectively. The authors recommend the use of paraffin in walnut grafting as a way to retain graft moisture and, accordingly, enhance callus formation. Mitrović and Blagojević (2002) evaluated the effect of different treatments on callusing and graft-take success and obtained the best results in the treatment involving paraffined foil-covered grafts, followed by paraffintreated grafts and paraffin non-treated grafts.
Foliar fertilisation in the present experiment resulted in a higher survival rate, a higher percentage of class 1 nursery trees and higher vegetative growth of nursery plants at the end of the first and second growing seasons. Paunović et al. (2011) underline the effect of foliar fertilisation on the survival and growth of walnut nursery trees. The survival of foliarly treated nursery trees in their study showed an $8.5 \%$ and $11.5 \%$ increase at the end of the first and second growing seasons, respectively, whereas their growth increase ranged from 1.6 to $3.0 \mathrm{~cm}$ at the end of the first growing season, and from 16.2 to $64.5 \mathrm{~cm}$ at the end of the second season, depending on cultivar. Solar (2003) achieved increased growth of walnut nursery plants upon foliar treatment. The treated nursery plants reached a height of $142-165 \mathrm{~cm}$, as opposed to untreated plants that attained a significantly lower height of about $96 \mathrm{~cm}$. Salifu et al. (2006) and Nicodemus et al. (2008) suggested that walnut fertilisation in the nursery increases the nutritive quality of grafted nursery trees, improves photosynthesis and physiological properties of walnut, enhances vegetative growth, and affects nutrient retention in root plugs, being of importance for the subsequent successful establishment of walnut orchards.

\section{Conclusions}

The obtained results suggest the necessity to treat grafts with paraffin and cover them with polyethylene foil during walnut grafting under controlled conditions in order to achieve higher graft-take success. The production of good quality healthy walnut plants under nursery conditions should necessarily involve the use of foliar treatment as an essential plant care practise, particularly during unfavourable weather, in order to reach an increased survival rate and improved vegetative growth of nursery plants.

\section{Acknowledgements}

This work was financially supported by the Ministry of Education and Science of the Republic of Serbia, Project No. 31064: Development and Preservation of Genetic Potential of Temperate Zone Fruits.

\section{References}

Avanzato D (2009). Training on hot callusing technique applied to walnut grafting. Walnut propagation training short course, COST Action 873, Spain, $10 \mathrm{p}$.

Bulatović S (1985). Walnut, hazelnut and almond. Nolit, Beograd, Serbia, 120-123 p.

Barut E (2001). Different whip grafting methods on walnut. Acta Hortic 544:511-513.

Hartman HT, Kester DE, Davies FTJr, Geneve RL (1997). Plant Propagation. Principles and Practices. $5^{\text {th }}$ Edition. PrenticeHall, New Jersey, 401 p.

Mitrović M, Blagojević M (2002). Formation on the callus in 
176 grafted walnut under different stratification modes. Proc Research Articles, Belgrade 8(2):35-40.

Mitrović M, Miletić R, Lukić M, Blagojević M, Rakićević M (2008). Impact of rootstock on callus formation in walnut grafted in room conditions. J Pomol 42(161-162):43-47.

Nicodemus AM, Salifu KF, Douglass FJ (2008). Growth, nutrition and photosynthetic response of black walnut to varying nitrogen sources and rates. J Plant Nutr 31:19171936.

Paunović MS (2010). Stratification and growth rate of grafted walnut. M. Sc. Thesis. University of Kragujevac, Faculty of Agronomy, Čačak, Serbia. Abstr 7-103.

Paunović MS, Miletić R, Mitrović M, Janković D (2011). Vegetative growth of walnut nursery plants as affected by foliar nutrition. J Pomol 45(173-174):55-60.

Paunović MS, Miletić R, Mitrović M, Janković D (2012). Effect of scionwood collection date on callus formation and grafting success in walnut. J Mountain Agric Balkans 15(4):895-900.
Solar A, Stampar F, Trost M (2001). Comparison of different propagation methods in walnut (Juglans regia L.) made in Slovenia. Acta Hortic 544:527-530.

Solar A (2003). The effects of foliar nutrition containing various macro and microelements on the growth and development of young grafted walnut (Juglans regia L.) plants. Intern J Hortic Sci 9:33-37.

Salifu KF, Jacobs DF, Pardillo G, Schott M (2006). Response on grafting Juglans nigra to increasing nutrient availability: growth, nutrition and nutrient retention in root plugs. Hortic Sci 41:1477-1480.

Tsurkan IP (1990). Production technology of English walnut planting materializing winter table grafting. Acta Hortic 284:65-68.

Tshering G, Gyyeltsen T, Lhendu T, Tshering U (2006). Effect of time of grafting on walnut graft success under different altitudes. Acta Hortic 705:303-307. 